\title{
NONCONCEPTUALISM AND CONTENT INDEPENDENCE
}

\author{
Sebastián Sanhueza Rodríguez ${ }^{1}$
}

\begin{abstract}
State Nonconceptualism is the view that perceptual states (not perceptual content) are different in kind from cognitive states (not cognitive content), insofar as a subject could be in perceptual states even if she lacked the concepts necessary to describe those states. Although this position has recently met serious criticism, this piece aims to argue on its behalf. A point I specifically want to highlight is that, thanks to State Nonconceptualism, it is possible to characterize perceptual experiences as nonconceptual or concept-independent without relying on the notion of perceptual content - a feature I term here the content independence of State Nonconceptualism. I think one should welcome this result: for, although a nonconceptualist characterization of perceptual experience is quite plausible, nonrepresentationalist approaches to perception have persuasively challenged the thought that perceptual experiences have representational content. This brief piece is divided into three parts: (i) I introduce two versions of Perceptual Nonconceptualism, namely, Content and State Nonconceptualism; (ii) I go on to stress State Nonconceptualism's content independence; and (iii), I briefly address three prominent objections against the state nonconceptualist.
\end{abstract}

Keywords: Nonconceptualism. Perceptual Content. Nonrepresentationalism

\section{INTRODUCTION}

Perceptual Nonconceptualism is often understood as the claim that perceptual experiences have contents different in kind from those of cognitive states, such as beliefs and judgements: in particular, perceptual content is nonconceptual. It has recently been argued, however, that there is an alternative way of understanding the nonconceptualist stance: according to this view,

${ }_{1}^{1}$ Assistant Professor, Department of Philosophy, University of Concepción, Concepción- Chile.

(D) https://orcid.org/0000-0001-7535-3482. E-mail: ssanhue@gmail.com.

Lecturer at the Faculty of Religious and Philosophical Sciences \& The Neuropsychology and Cognitive Neurosciences Research Center, Catholic University of Maule.

https://doi.org/10.1590/0101-3173.2021.v44n2.22.p325

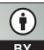

This is an open-access article distributed under the terms of the Creative Commons Attribution License. 
perceptual states (as opposed to perceptual content) are different in kind from cognitive states (as opposed to cognitive content) insofar as a subject could be in perceptual states even if she lacked the concepts necessary to describe those states (HECK JUNIOR, 2000; SPEAKS, 2005; CROWTHER, 2006; DUHAU, 2014). This proposal, increasingly known as State (as opposed to Content) Nonconceptualism, has been attacked by José Luis Bermúdez and Josefa Toribio, both being more sympathetic towards Content Nonconceptualism (BERMÚDEZ, 2007; TORIBIO, 2008; BERMÚDEZ AND CAHEN, 2015). In this brief piece, I aim to show that the relevant view is not as implausible as those writers depict it. I do so by pursuing a twofold strategy. First, I highlight a fairly underappreciated virtue of State Nonconceptualism, namely, that it formulates the core nonconceptualist thought-viz. that a distinctive feature of perceptual experiences is that they are nonconceptual-without relying on the notion of perceptual content. In principle, one could espouse the nonconceptualist distinction between experience and belief without settling down for one specific account of perceptual, nonconceptual content; or, most importantly, without endorsing a representationalist (that is, a content-based) view of perceptual experiences. Hardcore perceptual representationalists aside, we should welcome this result: if Nonconceptualism is conceived as a claim about the conditions under which a subject could instantiate perceptual states-a minimal claim which is in principle wholly non-committal about perceptual content-then discussions concerning that position and its main rival, Conceptualism, could be framed independently of the controversial question whether perceptual experiences have representational content. Secondly, I address some of the most prominent objections weighed against State Nonconceptualism: although I do not claim that they are definitely mistaken, I suggest that, as they stand, they are far from persuasive.

I divide this piece into three parts: first, I introduce State Nonconceptualism; secondly, I go on to stress State Nonconceptualism's content independence; and finally, I address three recent objections against the present view.

\section{INTRODUCING STATE NONCONCEPTUALISM}

Perceptual Nonconceptualism builds on a fairly straightforward thought: unlike beliefs and judgements, the perceptual experiences that a 
subject could have at a time do not depend on what conceptual repertoire she has at that time. The community between cognitively developed and undeveloped creatures as subjects of experiences supports that claim: even if babies and other primitive organisms lack the sort of conceptual repertoire (and hence, the beliefs and judgements) that a fully developed human creature has, it is in principle reasonable to ascribe perceptual experiences to all of them. In other words, perceptual phenomena do not seem to depend on concepts in the same way beliefs and judgements do.

The previous thought has been developed in two different ways. In this piece, I shall borrow Josefa Toribio's formulations of Content Nonconceptualism (CNC) and State Nonconceptualism (SNC) (TORIBIO, 2008, p. 354):

$C N C$ : For any perceptual experience $E$ with content $C, C$ is nonconceptual iff $C$ is essentially different in kind to the content of beliefs.

$S N C$ : For any perceptual experience $E$ with content $C$, any subject $S$, and any time $t, E$ is nonconceptual iff it is not the case that in order for $S$ to undergo $E, S$ must possess at $t$ the concepts that a correct characterization of $C$ would involve. ${ }^{2}$

According to CNC, perceptual experiences have a particular monadic property, viz. nonconceptual content. This is the claim that Gareth Evans apparently endorsed (EVANS, 1982) and that has dominated discussions on Perceptual Nonconceptualism ever since. As it is well known by now, the nonconceptualist faces two notable challenges. First, she has to specify the sense in which perceptual experiences have content. Secondly, she has to specify the sense in which perceptual content may be characterized as nonconceptual, a task which is complicated by the fact that the nonconceptual is a contrastive notion which depends on a previous understanding of what it is to be conceptual.

$\mathrm{SNC}$ is, in turn, a relative newcomer in the philosophical scene. According to this view, the instantiation of cognitive states like beliefs and judgements depends on the thinker's grasp of the concepts constituting the

${ }^{2}$ For other formulations of CNC and SNC, cf. SPEAKS (2005, p. 360); BERMÚDEZ (2007, p. 60); CROWTHER (2006, p. 252). 
contents of those states. Beliefs and judgements are thus constrained by a conceptual requirement. According to this view, perceptual experiences are not subject to that requirement: a subject could instantiate perceptual states even if she lacked the concepts required to provide a correct characterization of those experiences. It is a good question what kind of concept-independence is at stake here. Informational? Causal? Constitutive? All of them? Since I aim to outline SNC as a general blueprint for more specific accounts, I shall remain noncommittal about this point. Although I would personally build a constitutive understanding of concept-independence into SNC, the key point is that your preferred flavour of independence should match the specific sense of concept-dependence relevant to beliefs (among other cognitive propositional attitudes) that you choose. For the time being, the general thought I am most concerned with is that SNC is not a thesis about the content of perceptual experiences, but one about the relationship between the subject and the content of those experiences. I shall expand on this point in the next section.

It is worth stress noting that the previous depictions of CNC and SNC, as formulated here, does not provide a definition of nonconcept-independence. For exampleual content; it only states what it is for perceptual experiences to be nonconceptual, however the nonconceptual be exactly understood. In this piece, I haveam not interested on the questionexplored whether nonconceptual content should be understood in terms of scenarios (PEACOCKE, 1992), sets of possible worlds (STALNAKER, 1984), or Russellian propositions (TYE, 1995). And while both views eventually have to take a stance on this question, I remain neutral as to how concept-independence content should be understood at least for two reasons. First, as already mentioned, I wish to provide as flexible a formulation of SNC as possible. And second, the difference between the two varieties of nonconceptualism I am interested in turns on how they handle the notions of content rather than that of concept. Likewise, it is worth noting that, at the present level of generality, no specific account of concepts is yet endorsed. That said, it is important to stipulate that it cannot be too liberal: were concepts to be defined in terms of, say, sensorimotor or discriminatory skills (ARMSTRONG,1968; Noë 2012), they could be ascribed to the kinds of organisms-e.g. babies, among other non-human creatures-that partially motivate the claim that experience is concept-independence. 


\section{THE CONTENT INDEPENDENCE OF STATE NONCONCEPTUALISM}

A relatively underappreciated feature of State Nonconceptualism is that it detaches the main nonconceptualist claim about perception and cognition from claims about perceptual content. This is, I suspect, a significant point. Since its inception in the philosophical literature (that is, at least since Dretske 1981 and Evans 1982), Perceptual Nonconceptualism has developed in the context of discussions about the content of perceptual experiences. This historical contingency may naturally suggest that the nonconceptualist position call only be fleshed out along the lines of CNC-that is, in terms of a claim about perceptual content. If SNC is a coherent option, however, a characterization of perceptual experiences as nonconceptual would not necessarily presuppose that perceptual experiences have representational contents, let alone any specific form of nonconceptual content. One could express this point saying that Nonconceptualism is independent from claims about perceptual content (for short, content independent) or neutral about perceptual content (for short, content neutral). In this section, I aim to do three things: first, to bring out the content independence of SNC; secondly, to stress how that feature shapes our understanding of SNC; and thirdly, slightly to reformulate $\mathrm{SNC}$ so as to reflect that feature.

To begin with, then, let me expand on SNC's content independence. This feature seems to be one of the position's main motivations. Listing some of the reasons in favour of SNC, Bermúdez and Arnon Cahen remark that this view

[...] allows for a meaningful debate about Nonconceptualism even if one holds that all content is nonconceptual. Stalnaker (1984, 1998), for example, argues that all content should be understood in terms of sets of possible worlds. If that is the case, then the difference between the propositional attitudes and perception should be elucidated in terms extrinsic to the type of content involved in these states (BERMÚDEZ; CAHEN 2015: section 3).

Even if perceptual contents are by definition nonconceptual, SNC is intended to allow for a meaningful distinction between perceptual experiences and beliefs in terms of concept-independence and concept-dependence. Mutatis mutandis, I think one could also claim that SNC makes sense of the nonconceptualist distinction between perceptual experiences and beliefs even if perceptual content is by definition characterized as conceptual. That said, 
the main claim of this section is that the relevant position could be taken even further: specifically, SNC could make sense of the nonconceptualist distinction between perception and cognition without even assuming whether perceptual experiences have representational content.

The importance of SNC's content independence is best appreciated in the light of what may be called Perceptual Nonrepresentationalism. Discussions concerning Perceptual Nonconceptualism developed under the general assumption that perceptual experiences are representational or have content. This assumption was even shared by the nonconceptualist's main rival, a conceptualist view according to which perceptual experiences are concept-dependent in a sense germane to that in which cognitive states or events are concept-dependent (McDOWELL, 1994; CHUARD, 2007). Following Bill Brewer, I shall understand here the representationalist view as a combination of two main claims: (i) that perceptual experiences should be fundamentally characterized in terms of their representational content, that is, in terms of how things are represented in experience to the subject; and (ii), that such a representational content could not be further analysed in terms of a more primitive relation of acquaintance between the subject of experiences and the objects of perception (BREWER, 2011: ch. 4). A nonrepresentationalist stance, by contrast, crucially rejects (ii): that is, it asserts that perceptual experience can and should be ultimately analysed in terms of an acquaintance- or awareness-relation between subject and object. In fact, Nonrepresentationalism is more accurately conceived not as a homogeneous line of thought, but as a family of different positions that share a rejection of a representational framework as the fundamental model for describing perceptual experiences. ${ }^{3}$ For present purposes, the relevance of Nonrepresentationalism is that, if the latter view is ultimately correct (a point on which I remain neutral here), the nonconceptualist distinction between experience and belief could not be drawn in terms of CNC: whereas $\mathrm{CNC}$ aims to provide a fundamental distinction between experience and belief, Nonrepresentationalism (per the rejection of (ii)) entails that such a distinction do not reach the fundamental difference between these psychological categories.

On the basis of the previous predicament, SNC has an obvious virtue over CNC: since it concerns states rather than contents, it could capture a fundamental distinction between perception and belief even on the face

3 To compare different nonrepresentationalist views, cf. CAMPBELL (2002, 2009); FISH (2009); BREWER (2011). 
of Nonrepresentationalism. Whether perceptual experiences should be analysed in representational or relational terms, one could still characterize perceptual attitudes as concept-independent. Of course, by relying on the state nonconceptualist proposal, one still has to specify, first, a suitable notion of content for cognitive phenomena, and secondly, a notion of concept in relation to which perceptual phenomena could be characterized as concept-independent. But I take it that both representationalists and nonrepresentationalists concede that these tasks can and should be addressed. Thus, an important virtue of SNC is that it makes sense of a distinction driving good part of the philosophical discussion on perception during the last thirty years, and it does so independently of the controversial representationalist framework.

To appreciate the implications of SNC's content independence, it is worth examining what bearing that feature has on (a) how this nonconceptualist position is currently construed and (b) how it is related to CNC. To begin with, there are at least two respects in which SNC's formulation seems to depend on the notion of perceptual content. (1) Since SNC is often presented as a claim about the relationship between the subject and the content of perceptual experiences, the notion of perceptual content apparently enters into its characterization: the state nonconceptualist takes a stance (however implicit it may be) in favour of a representationalist model of perceptual experience. As previously mentioned, however, this assumption is not regarded as entirely innocent nowadays. (2) Since SNC distinguishes perceptual experiences from beliefs in terms of the relevant states, it is often assumed that both psychological categories have the same kind of content an assumption I shall term the Same Content Thesis. To take just one example, Bermúdez (2007, p. 66) claims: "[a]ccording to the state view, [...] there is only one type of content. Perceptual experiences and propositional attitudes have contents of the same type." (HECK JUNIOR, 2000, p. 485; TORIBIO, 2008, p. 354-355; DUHAU, 2014). Even though most writers tend to assume that SNC is saddled with the Same Content Thesis, I think we should be more cautious: by endorsing that thesis, the state nonconceptualist would renounce to a content independent way of setting experiences apart from beliefs; as part of a fundamental description of perceptual phenomena, she would presuppose that perceptual experiences have representational content and, more specifically, that perceptual content is of the same kind as doxastic content. To respect the feature of content independence, I think SNC should 
not refer to perceptual experiences' possession of content, let alone to a specification of what kind of content perceptual experiences have.

Turning to (b) now, the feature of content independence should also shape the way in which the relationship between CNC and SNC is understood. To flesh out the logical distinction between CNC and SNC, Thomas Crowther attempted coherently to combine $\mathrm{CNC}$ with a conceptualist stance about perceptual states (that is, with what might be called State Conceptualism) and SNC with a conceptualist stance about perceptual content or Content Conceptualism (CROWTHER, 2006). In reply, Toribio tried to show that SNC actually entails CNC, and hence, that the former does not constitute a legitimate philosophical position over and above the latter (TORIBIO, 2008). This line of attack, however, is misplaced at least for two reasons. First, Crowther only needs to show that there is a conceptual distinction between content and attitude at the level of perceptual phenomena: in other words, all he has to do is to show that CNC is not a definition of SNC. Beyond this point, I suspect the state nonconceptualist could perfectly concede that SNC and CNC are not mutually exclusive (which Crowther takes for granted) or that SNC entails CNC (which, although Crowther himself does not assert, neither does he deny by principle). Secondly, the state nonconceptualist could take the distinction between SNC and CNC further by endorsing SNC and Perceptual Nonrepresentationalism. Indeed, the logical entailment pointed out by Toribio necessarily breaks down when one characterizes perceptual experiences as concept-independent and, at the same time, refuses to analyse experiences in representational terms. As far as I can see, there is no obvious contradiction between Nonconceptualism and Nonrepresentationalism: if this view is coherent, Toribio's line of attack would definitively fail.

The main claim of this section is then that, to exploit its full potential vis-à-vis CNC, SNC should highlight the feature of content independence. That is, when Nonconceptualism is understood as a claim about perceptual and doxastic states, one could differentiate perceptual experiences from cognitive states in a way that remains neutral about the question whether experiences have representational content. As I pointed out a bit earlier, this neutrality about perceptual content constitutes a key virtue of SNC over CNC: by remaining non-committal about perceptual content, the nonconceptualist could use the notion of concept-independence to latch onto a distinctive trait of perceptual experience, no matter what conception of perceptual experience 
one imported into this discussion. ${ }^{4}$ I thus think that a minimal formulation of the state nonconceptualist view should hold on to content independence - that is, it has to remain neutral as to how the relevant perceiver relates to perceptual content or as to whether perceptual experiences have content at all: that way, it would be a legitimate view even if one, say, rejects that perceptual experiences have content or stipulates that perceptual content is conceptual.

In view of the foregoing remarks, SNC could be slightly rephrased as follows:

$S N C^{*}$ : For any perceptual experience $E$, any subject $S$, and any time $t$, $E$ is nonconceptual, iff it is not the case that in order for $S$ to undergo $E, S$ must possess at $t$ any particular concept.

As far as I can see, this formulation remains loyal to the spirit of SNC. Like SNC, it concerns perceptual attitudes, not perceptual contents. Unlike SNC, SNC* does not pick up on the sub-set of concepts one would use to specify the content of perceptual experiences; it simply stipulates that an organism could have perceptual experiences even if she lacked any particular sub-set of concepts or conceptual capacities. Hence, SNC* remains neutral about perceptual content. This reformulation is not aimed to compete against or supersede SNC: all it aims to do is to highlight an otherwise underappreciated feature of SNC, namely, its content independence. ${ }^{5}$

\section{OBJECTIONS AGAINST STATE NONCONCEPTUALISM}

I conclude this piece by briefly addressing three prominent objections against SNC.

${ }^{4}$ One caveat. As understood here, SNC is not simply a reformulation of what is known as the Autonomy Thesis, that is, the thesis according to which there could be subjects of experience lacking any repertoire of concepts (PEACOCKE, 1994; BERMÚDEZ, 1994). Like CNC, SNC could make do with or without that thesis. What SNC primarily asserts is that the existence of perceptual states need not depend on the possession of one or another set of concepts. This view can be endorsed even if one grants that, as a matter of fact, most perceiving creatures incorporate certain conceptual capacities. Thanks to an anonymous referee for asking me to clarify this point.

5 Duhau (2014) develops an alternative way of defending State Nonconceptualism: after granting that the Same Content Thesis is part of SNC, she seeks to defuse the tension between CNC and SNC by showing that both positions rest on different notions of content. I naturally avoid this path, as it obscures the content independence of SNC by stipulating different notions of content: this, I think, unnecessarily complicates our understanding of the relationship between CNC and SNC. 
First Objection: Implausible Perceptual Content. SNC is apparently committed to an implausible notion of perceptual content. As previously mentioned, Bermúdez takes SNC to incorporate what I called the Same Content Thesis, that is, the thought that perceptual experiences and cognitive states like beliefs have the same kind of content. As such, he thinks that the state nonconceptualist is forced to model perceptual content in the image of doxastic content, and this is admittedly problematic. For, if perceptual content is conceived in terms germane to doxastic content, e.g. Fregean modes of presentations or sets of possible worlds, it will be at least mysterious how a perceiver's relation to those abstract entities will account for the way that things appear (e.g. look, smell, taste, etc.) to the perceiver (BERMÚDEZ, 2007, p. 67). Toribio presses a structurally similar line of thought: in her case, the main point is that it is extremely difficult to see how perceptual content, when conceived as sets of possible worlds or as Russellian propositions (that is, complexes of worldly objects and properties), could account for the finegrained way in which perceptual experiences can be individuated (TORIBIO, 2008, p. 356ff.).

Reply: Reject Same Content Thesis. One way of addressing this objection consists in showing that the accounts of perceptual content that Bermúdez and Toribio dismiss could actually be articulated in plausible ways. This is a task that remains pending here. A simpler solution, I think, is to reject that the state nonconceptualist should be committed to the Same Content Thesis. SNC does not have to incorporate the assumption on which Bermúdez's or Toribio's attacks rest, namely, that perceptual experiences should have the same content as beliefs and judgements; hence, it is not forced to shape perceptual content in the same way it understands cognitive content.

Second Objection: Avoiding Explanatory Circularity. The notion of perceptual content is necessary for understanding a key motivation behind a nonconceptualist position, namely, the possibility of providing a non-circular account of observational concepts. As Bermúdez says, one way of accounting for what it is to possess observational concepts consists in invoking a subject's capacities to discriminate objects and properties of the distal environment; but unless this explanation be circular, such capacities of perceptual discrimination cannot rely on the concepts they try to explain - hence the point of conceiving such capacities in nonconceptual terms (BERMÚDEZ 2007, p. 67-68). But Bermúdez goes on to press the following challenge: 
[...] what explains those discriminative abilities? Plainly, the perceptual discriminations that a subject can make are a function of how things looks to her-that is, they are a function of what she perceives, or, in the terms we have been using, of the content of her perception. But it is hard to see where these explanations are going to bottom out on the state view (BERMÚDEZ, 2007, p. 68).

Reply: the Primitive Status of Perceptual Discrimination. It is true that SNC should eventually address the question how perceptual states relate to discriminatory behaviour; but since this essay does not pretend to offer a fullfledged defence of that view, I do not pursue it here. What I want to do here is to point out that Bermúdez's objection is inconclusive. He claims that a perceiver's discriminatory behaviour is a function of the way things appear to a subject, that is, of the content of her perceptual experiences. But this claim is not obviously correct. There are two other ways in which one could relate a perceiver's discriminatory behaviour and the way things appear to her: (i) one could reverse Bermúdez's claim and argue that how things look to a subject is a function of what that subject can perceptually discriminate; or (ii) one could collapse both notions, so as to claim that how things appear to a subject amounts to nothing over and above what she can perceptually discriminate - a stance I find intuitively more plausible than the other two alternatives. ${ }^{6}$ Whether she endorses (i) or (ii), the state nonconceptualist could thereby invoke capacities of perceptual discrimination without invoking perceptual content as a more fundamental explanatory notion. Indeed, one will have to say something like that if one rejects the whole representationalist framework. Hence, Bermúdez's objection rests on the fragile premise that his assumption (that is, what a perceiver can perceptually discriminate is a function of what contents she perceptually represents) is a better option than (i) or (ii). Although the state nonconceptualist has to take a stance on this point, it is unclear that her story about the link between perceptual states and perceptual discrimination has to rely on the notion of perceptual content.

\footnotetext{
${ }^{6}$ To take just one example, George Pitcher contends that "[...] the way things look to a perceiver is a matter of the ways he is disposed to act towards them as the result of using her eyes in the standard visual way - t put it much too crudely." (PITCHER, 1971, p. 167) (Pis is another way of saying that how things look to a perceiver is a function of how that perceiver is disposed to behave-here perceptual discrimination is taken to be a form of behaviour. This claim is germane to the (controversial but, in my view, not implausible) dispositional views of perception endorsed by Pitcher and David Armstrong (1968, specially chs. 10 and 11).
} 
Third Objection: Unmotivated View. State Nonconceptualism is unmotivated. According to Bermúdez, "[...] the state view proposes a principled distinction between concept-dependent state-types and conceptindependent state-types. Plainly, proponents of the distinction owe us an account of where it comes from. Why is it the case that beliefs do, while perceptions do not, respect the conceptual constraint?" (BERMÚDEZ, 2007, p. 68) Likewise, Toribio presses that "[...] the real question is why believing, but not perceiving, is thus constrained by concept possession." (TORIBIO, 2008, p. 357) The general worry may be put as follows: claiming that perceptual experiences are concept-independent, and beliefs, concept-dependent, only solves the question how perceptual experiences are distinctively different from beliefs and judgements; but the state nonconceptualist has not yet addressed the question why perceptual experiences are concept-independent.

Reply: 'Tu Quoque' \& Functional Role of Perception. In principle, one could argue that $\mathrm{CNC}$ faces exactly the same why-question, whereby SNC would not be on a worse starting point. But one could also develop a more constructive line of thought: it is unclear to me why a functional characterization of perceptual experience and belief would fail addressing the previous question. Unlike cognitive events and states, perceptual phenomena could be functionally characterized as informational transactions by means of which perceivers relate to their surroundings. As graphically put by David Armstrong,

[...] the organism can take account of the environment only if the environment affects the organism: affecting it in different ways for different states of the environment. These affections are perceptions. So the fact that perceptions of the environment are brought into being by that environment pertains to the deepest essence of perception (ARMSTRONG, 1968, p. 255).

Functionally conceived, perceptual phenomena concern the ways in which perceiving organisms are affected by their surroundings. That being the case, one could extract the following line of reply to the question why perceptual states need not be concept-dependent: these states may, but need not be concept-dependent because they are primarily or derivatively constituted by informational interactions between the perceiver and her surroundings; on the other hand, since cognitive phenomena (e.g. believing or judging) are not characterized in terms of the same kind of informational transactions, 
something other than the world has to take its place in the constitution and individuation of these states or events - at this point, it seems reasonable to think that what a subject believes or judges constitutively depends on what concepts she has. In short: while the constitution of perceptual experiences relies on worldly items - that is, insofar as perceptual experiences result from a subject's sensory organs being affected by the world - the constitution of beliefs and judgements relies on concepts and propositions. This does not rule out that some perceptual experiences could be concept-dependent or that some cognitive states (e.g. demonstrative thoughts) could be objectdependent, but it shows why perceptual experiences need not be conceptdependent. Concepts do for cognitive states what the world does for perceptual experiences. Although this picture is no doubt sketchy as it stands, I think it is fairly intuitive.

This essay has thus not aimed to provide a full defence of State Nonconceptualism, but only to explain how it should be formulated. This seems a crucial preliminary step in the debate concerning two conceptions of Nonconceptualism.

RODRÍGUEZ, S. S. No-conceptualismo e independencia de contenido. Trans/form/ação, Marília, v. 44, n. 2, p. 325-340, Abr./Jun, 2021.

Resumen: El No-Conceptualismo de Estados es la posición según la cual estados (no contenidos) perceptivos son diferentes en especie respecto a estados (no contenidos) cognitivos, en la medida en que un sujeto podría instanciar ciertos estados perceptivos aun si careciera de los conceptos necesarios para describir dichos estados. Aunque esta posición ha sido objeto de críticas recientemente, este artículo argumenta a favor de ella. Un punto que quiero especialmente poner de relieve es que, gracias al No-Conceptualismo de Estados, es posible caracterizar nuestras experiencias perceptivas como noconceptuales o conceptualmente independientes sin depender de la noción de contenido perceptivo un atributo que denomino aquí la independencia de contenido del No-Conceptualismo de Estados. Creo que este resultado es bienvenido, ya que, mientras que una caracterización no-conceptualista de las experiencias perceptivas es bastante plausible, enfoques no-representacionalistas de la percepción han persuasivamente cuestionado la idea de que las experiencias perceptivas tengan contenido representacional. Este breve ensayo se divide en tres partes: (i) introduzco dos versiones del NoConceptualismo Perceptivo, a saber, el No-Conceptualismo de Contenidos y el de Estados; (ii) pongo de relieve la independencia de contenido del No-Conceptualismo de Estados; y (iii), brevemente me encargo de tres objeciones en contra del no-conceptualista de estados.

Palabras Claves: No-Conceptualismo. Contenido Perceptivo. No-Representacionalismo. 


\section{REFERENCES}

ARMSTRONG, David Malet. A Materialist Theory of the Mind. London: Routledge, 1968.

BERMÚDEZ, José Luis. Peacocke’s Argument against the Autonomy of Nonconceptual Representational Content. Mind \& Language, v. 9, 1994, p. 402-418.

BERMÚDEZ, José Luis. What Is at Stake in the Debate on Nonconceptual Content? Philosophical Perspectives, v. 21, 2007, p. 55-72.

BERMÚDEZ, José Luis; ARNON, Cahen. Nonconceptual Mental Content. In: The Stanford Encyclopedia of Philosophy, Fall, 2015.

BREWER, Bill. Perception and Its Objects. Oxford: Oxford University Press, 2011.

CAMPBELL, John. Reference and Consciousness. Oxford: Oxford University Press, 2002.

CAMPBELL, John. Consciousness and Reference. In: McLAUGHLIN, Brian; BECKERMANN, Ansgar (ed.). The Oxford Handbook of Philosophy of Mind. Oxford: Oxford University Press, 2009, p. 648-662.

CHUARD, P. The Riches of Experience. Journal of Consciousness Studies, v. 14, p. 20-42, 2007.

CROWTHER, T M. Two Conceptions of Conceptualism and Nonconceptualism. Erkenntnis, v. 65, n. 2, 2006, p. 245-76.

DRETSKE, Fred. Knowledge and the Flow of Information. Cambridge, MA: The MIT Press, 1981.

DUHAU, Laura. Perceptual Nonconceptualism: Disentangling the Debate between Content and State Nonconceptualism. European Journal of Philosophy, v. 22, 2014, p. 358-370.

EVANS, Gareth. The Varieties of Reference. Oxford: Clarendon Press, 1982.

FISH, William. Perception, Hallucination, and Illusion. Philosophy of Mind Series. New York: Oxford University Press, 2009.

HECK JUNIOR, Richard G. Nonconceptual Content and the 'Space of Reasons.' The Philosophical Review, v. 109, n. 4, 2000, p. 483-523.

MCDOWELL, John. Mind and World. Cambridge, MA: Harvard University Press, 1994.

NOË, Alva. Varieties of Presence. Cambridge, MA: Harvard University Press, 2012. PEACOCKE, ChristopheR. A Study of Concepts. Cambridge, MA: The MIT Press, 1992. 
PEACOCKE, Christopher. Nonconceptual Content: Kinds, Rationales and Relations. Mind and Language, v. 9, 1994, p. 419-429.

PITCHER, George. A Theory of Perception. Princeton: Princeton University Press, 1971.

SPEAKS, J. Is There a Problem about Nonconceptual Content? The Philosophical Review, v. 114, n. 3, 2005, p. 359-398.

STALNAKER, Robert. Inquiry. Cambridge, MA: The MIT Press, 1984.

STALNAKER, Robert. What Might Nonconceptual Content Be? Philosophical Issues, v. 9, 1998, p. 339-352.

TORIBIO, Josefa. State versus Content: The Unfair Trial of Perceptual Nonconceptualism. Erkenntnis, v. 69, 2008, p. 351-361.

TYE, Michael. Ten Problems of Consciousness: A Representational Theory of the Phenomenal Mind. Cambridge, MA: The MIT Press, 1995.

Recebido: 13/3/2019

Aceito: 30/6/2020 
RODRÍGUEZ, S. S. 